\title{
A NEW SPECIES OF NEONYMPHA.
}

BY G. H. FRENCH, CARBONDALE, ILL.

Neonympha Mitchellii n. sp.

Expanse of wings, male, r.20 to I.30 inches; female inches.

Male.--Upper surface grayish wood-brown, rather dark, without spots or marks, except that the spots on the underside of the hind wings and the dark lines bordering the terminal dark yellow line on the same wings show through a little. Fringes concolorous, in certain lights a little smoky tinged. Under surface slightly paier than the upper, a little more of the mouse order of color, sprinkled with buff scales. Both wings are crossed by four transverse brownish-yellow stripes, so dark on the fore wings as to be yellow-brown, occupying the same position as the same lines in its ally, $N$. Areolatus, the first and second uniting by a rounded end about a tenth of an inch from the inner margin of hind wings, the two outer-one terminal and the other sub-terminal-also uniting before reaching anal angle. In Areolatus these lines do not unite. Each of these lines has a dark brown (more or less distinct) fine bordering line on each side of it. The first line crosses the fore wings a little more than two-thirds the distance from the base of wing to end of cell, the hind wings about twothirds. The second line crosses fore wing a little beyond the end of celi, the hind wings across the end of cell. The second and third are approximate anteriorily as in Areolatus. Fore wings with a row of four small ocelli between second and third lines, black, circled with pale Naples yellow or buff, the first varying from a dot, the size of an ordinary period, to about twice that diameter; in four examples circular, in two a little oval, in two a silvery metallic centre, the second a little more than twice the diameter of the first; in three examples circular, the other three slightly ovate, each with from one to three metallic points, when three present in the form of a triangle ; the third averaging the size of the second, circular, with from one to two metallic points, when one central, when two in line with the row of spots; the fourth about one-fourth larger than the first, circular, all but one, which has the buff circie almost complete on the outside, but also a few buff scales outside the circle, a single metallic point to each of these.

Hind wings with six ocelli to each wing, circled with buff as those on 
the fore wings. The first varying from a few buff scales, in one example, without the black centre, to twice or thrice the diameter of an ordinary period, circular, the largest with, in one example, a silvery metallic point; the second about .04 of an inch in diameter (the black portion), circular in four examples, in two a slight bulging in outer anal part, from one to five metallic scales, aggregated or scattered; the third from .06 to .07 of an inch in diameter, all nearly or quite circular, two silvery metallic points, in line with the ocelli; the fourth size of the third and the same shape. In each of these one example has a few black scales projecting into the buff annulus externally on one wing, points as in the third, except that in one the metallic scales are scattered on one wing; fifth of the size of the third, circular, in one example a few buff scales invade the black externally on one wing, in two other examples they are a little irregular in shape externally on both wings, two metallic points to each, with a few scattering scales in two examples; sixth about constant in size, as large as the largest of the first, one metallic point in all but one, ocellus, where the scales scatter a little, circular.

Body concolorous; antennæabove on basal two-thirds colour of wings, terminal orange shading into basal colour; beneath whitish, outer third orange; sides of basal two-thirds brown and whitish.

Female.-Differs from the male in being paler both above and below, and slightly in the arrangement of the transverse lines on the under side. In two of the four before me, the second and third lines distinctly unite with each other near the anal angle, while the lines by which the first and second, and the third and fourth unite are to be seen but are obscure. In one of the others there is no union between the second and third, while there is plain union between first and second, and third and fourth. The fourth has a distinct union between the first and second, and third and fourth, but the rounded ends of these unions touch. Both wings of the same example alike in this character. Ocelli as in the males, with about the same amount of variation.

This species differs from $A$. Areolatus in the following points:-In Arcolatus the fore wing may have three ocelli and vary from that to many, while the hind wings have five. In Mitchellii four are always found on the under side of the fore wings, and six on hind wings in both sexes. In Areolatus the ocelli are elongate, the long part the long way of the wing. In Mitchellii they are all circular with only a littie variation. 
In Areolatus the metallic points in the ocelli are pale blue, and are arranged more or less in rows in the ocelli lengthwise of the wing. In Mitchellii they are, if in rows at all, across the wing. In Areolatus the transverse lines on the under side are ferruginous, and the second and third always unite near anal angle of hind wings. In Mitchellii they are more of a brownish-yellow; in the males the second and third lines never unite, but the first and second, and the third and fourth always unite leaving a little space between their rounded ends; in the females only one out of four had the second and third distinctly united. In Areolatus the metallic points are pale blue. In Mitchellii they are lighter, being more of a silvery colour, giving none of the real blue reflection, unless seen at a very oblique light, and then very pale.

Described from six males and four females taken by my friend, Professor J. N. Mitchell, in Cáss County, Michigan, to whom I dedi cate the species. They were found in upland dry meadows, about ten miles from the Indiana line. Professor Mitchell is of the opinion that the species has been found as far north as Kent County, Michigan.

\section{TWO NEW SPECIES OF TINEIDA FROM THE ALEUTIAN ISLANDS.}

BY WM. BEUTENMULLER, NEW YORK.

Cerostoma Aleutianella, n. sp.

Head and palpi olive gray; legs olive gray, tibiæ annulated with fuscous ; body fuscous. Primaries olive gray, becoming paler toward the outer margin; above the fold is a broken fuscous basal streak, running to a little beyond the middle of the wing; at the end of the cell a small fuscous spot, limited beneath by a white patch. Cilia olive gray. Secondaries grayish fuscous. Underside of wings grayish fuscous. Cilia of the primaries tipped with greenish gray.

Expanse $20 \mathrm{~mm}$. I $\delta$. Coll., Hy. Edw.

Cerostoma Dubiosella, n. sp.

Head, thorax and palpi fuscous. Primaries grayish fuscous, thickly covered with deep fuscous scales; before the outer margin a few white and black scales. Secondaries grayish fuscous, as are also the underside of the wings.

Expanse $18 \mathrm{~mm}$. One example. Coll. Hy. Edw. 